\title{
Comparative karyomorohplogical studies in four species and one variety of Mosla Buch.-Ham. ex Maxim. (Lamiaceae) in Japan
}

\author{
Tsuneo Funamoto ${ }^{1,4}$, Makoto Ogawa ${ }^{2}$ and Shungo Kariyama ${ }^{3}$ \\ ${ }^{1}$ Biological Institute, Fundamental Education and Research Center of Pharmaceutical Sciences, Showa \\ Pharmaceutical University, 3-chome, Higashi-Tamagawagakuen, Machida city, Tokyo 194-8543, Japan; \\ ${ }^{2}$ Tokushima Prefectural Museum, Bunka-no-mori, Hachiman-cho, Tokushima city, Tokushima 770-8070, Japan; \\ ${ }^{3}$ Kurashiki Museum of Natural History, Chuo-2, Kurashiki city, Okayama 710-0046, Japan \\ ${ }^{4}$ Author for correspondence (funamoto@ac.shoyaku.ac.jp) \\ Received October 15,2013; accepted April 1, 2014
}

\begin{abstract}
Karyomorphology of four species and one variety of Japanese Mosla were observed. They had commonly chromosomal characters at resting nuclei of the complex chromocenter type, and the mitotic metaphase cells showed $2 \mathrm{n}=36$ for M. japonica, $2 \mathrm{n}=18$ for $M$. chinenis, M. scabra, M. dianthera and M. dianthera var. nana. The chromosome numbers of $2 \mathrm{n}=18$ and 36 were considered diploid and tetraploid, respectively if the basic number $\mathrm{x}=9$ was accepted. The chromosome number of $2 \mathrm{n}=18$ for $M$. dianthera var. nana was reported here for the first time, and that of the other four species were verified with the previous reports. The karyotypes of five taxa had commonly similar karyomorphology to each other except for chromosome numbers; small sized chromosomes (2.2 to $1.1 \mu \mathrm{m}$ long), mono-modal (gradual) decrease in chromosome length from the longest to the shortest chromosomes, and consists of median- and submedian-centromeric chromosomes.
\end{abstract}

KEYWORDS: Japan, Karyomorphology, Lamiaceae, Mosla, Subtribe Perillinae

The genus Mosla Buch.-Ham. ex Maxim. is one of the three genera in the subtribe Perillinae Briq., the family Lamiaceae (Labiatae), consists of about 22 species (Wu and Li 1977b; Li and Hedge 1994), that are commonly annual herbs and aromatic plants, and grow in grassy slopes, forest margins, hills thickets, open hills and stream-sides in temperate regions of India, Southeast Asia and East Asia. Among the species of this genus, 12 species are found in China (Li and Hedge 1994) and four species and one variety grow in Japan (Murata and Yamazaki 1993).

Seven species (including a synonym) of Mosla have been cytologically studied previously and documented their chromosome numbers as $n=9,2 n=18$ and $2 n=36$ (e.g., Sugiura 1931; Suzuka 1953; Mehra and Gill 1968; Gill 1971, 1984; Probatova and Sokolovskaya 1986; Sokolovskaya et al. 1986; Zhang and Xu 1988; Hsieh and Huang 1999), and these studies are only chromosome numbers reports.

This paper reports detailed karyomorpholoies (the resting nucleus and the mitotic metaphase chromosomes) in the Japanese species of Mosla.

\section{Materials and Methods}

Sixty-nine plants of four species and one variety of Mosla were collected in 14 localities in Japan (Fig. 1; Table 1), and cultivated in unglazed plant-pots in shade place in the experimental garden of Showa Pharmaceutical University. Chromosome observations were made in meristematic cells of fresh root tips. They were cut off 5-10 mm long and pretreated in $2 \mathrm{mM} 8$-hydroxyquinoline at ca $20^{\circ} \mathrm{C}$ for $4 \mathrm{~h}$ and then fixed in $45 \%$ acetic acid at ca $2^{\circ} \mathrm{C}$ for $10 \mathrm{~min}$. They were macerated in a mixture of $45 \%$ acetic acid and
$1 \mathrm{~N}$ hydrochloric acid $(1: 1)$ at ca $60^{\circ} \mathrm{C}$ for $20-23 \mathrm{sec}$ and were then stained with $2 \%$ aceto-orcein at room temperature in moist chamber with $45 \%$ acetic acid for ca $30 \mathrm{~min}$ and were prepared by the conventional squash method. The slides were faintly heated under an alcohol frame for 1-2 sec before observation. Measurements of chromosome length were made in each average length in several good metaphase cells.

Morphological type of the resting nuclei was classified for Tanaka (1971, 1977), and classifications of mitotic metaphase chromosomes followed Levan et al. (1964). Taxonomical treatment followed Murata and Yamazaki (1993). The voucher specimens of the plants used in this study were deposited in Funamoto's Herbarium in Showa Pharmaceutical University.

\section{Results and Discussion}

Five species of Mosla in Japan such as M. japonica (Benth. ex Oliv.) Maxim., M. chinensis Maxim., M. scabra (Thunb.) C. Y. Wu et H.W. Li, M. dianthera (Buch.-Ham. ex Roxb.) Maxim. and M. dianthera var. nana (Hara) Ohwi had common karyomorphological characters in the resting nucleus as the complex chromocenter type which had numerous chromomeric granules, fibrous threads and chromatin blocks and the small chromatin blocks were irregular in shape and varied in number in the whole region (Fig. 2A, D, F, H and J). This resting nucleus type is the same type as the other genera in Lamiaceae (eg; Funamoto 2007; Funamoto et al. 2008, 2009, 2011 and 2012). The mitotic metaphase chromosomes in these five taxa had commonly small sized chromosomes and monomodal (gradual) degraded in the chromosome length from the longest to the shortest chromosomes, and thus, formed 


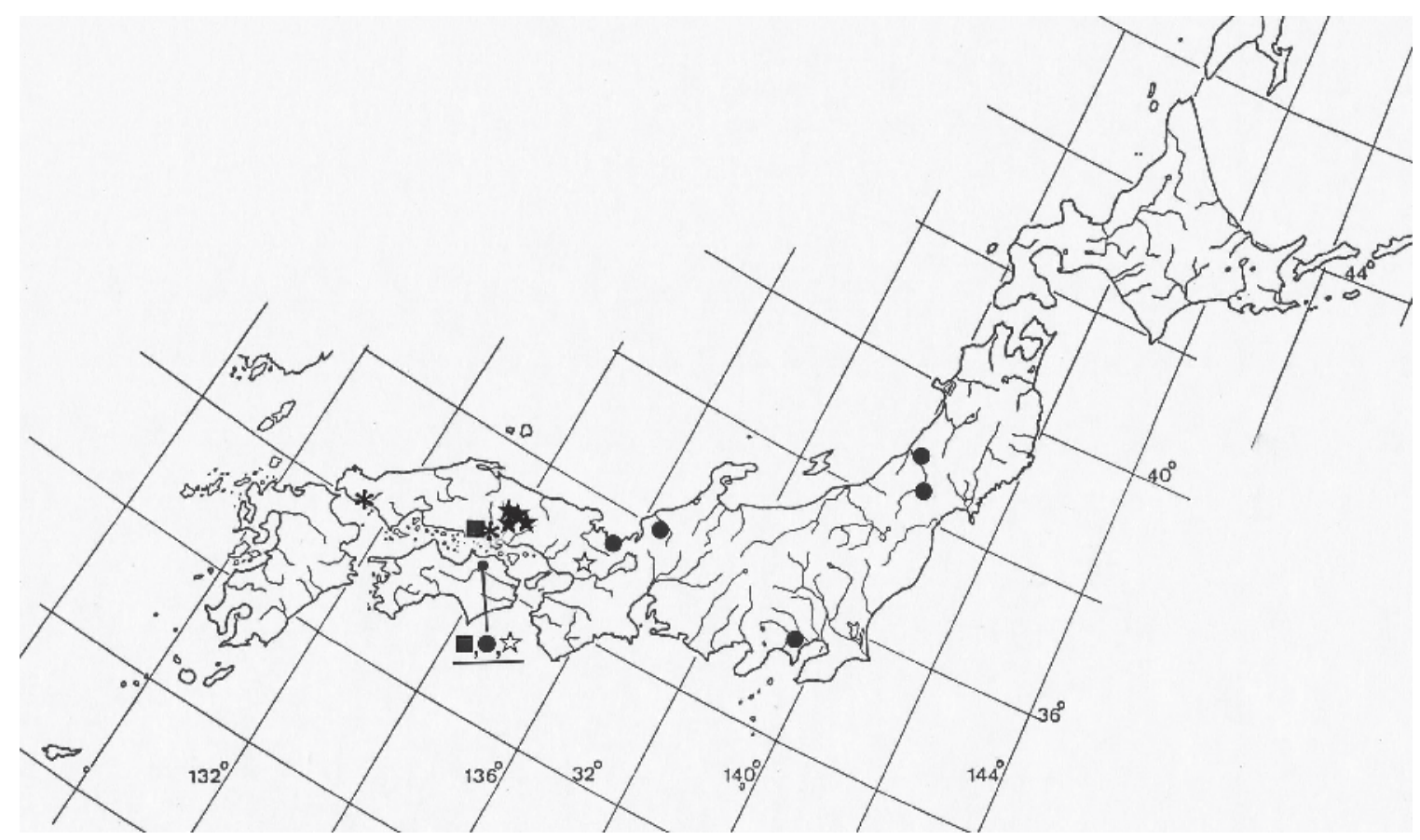

Fig. 1. Map of collection sites of five taxa of Mosla in Japan.

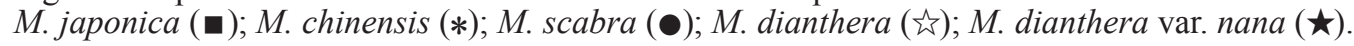

Table 1. Collection sites, sample numbers and chromosome numbers in four species of Mosla in Japan

\begin{tabular}{|c|c|c|c|}
\hline Species & Collection site & $\begin{array}{l}\text { Sample } \\
\text { number }\end{array}$ & $\begin{array}{l}\text { Chromosome } \\
\text { number }(2 n)\end{array}$ \\
\hline \multirow[t]{2}{*}{ M. japonica } & Okayama Prefecture, Kurashiki City, Mizue, Mt. Hachiman, alt. $100 \mathrm{~m}$ & 4 & 36 \\
\hline & Tokushima Pref., Miyoshi City, Ikeda-cho, Mt. Wakasamine, alt. 770 m & 2 & 36 \\
\hline \multirow[t]{2}{*}{ M. chinensis } & *Okayama Pref., Kurashiki City, Ikusaka, $34^{\circ} 37^{\prime} 91^{\prime \prime} \mathrm{N}, 133^{\circ} 46^{\prime} 84^{\prime \prime} \mathrm{E}$, alt. $50 \mathrm{~m}$ & 6 & 18 \\
\hline & $\begin{array}{l}\text { Yamaguchi Pref., Yamaguchi City, Aio-futajima, Senbo-gawa Kasen Park, } 34^{\circ} 02^{\prime} 16^{\prime \prime} \mathrm{N}, 131^{\circ} 26^{\prime} \\
97^{\prime}, E \text {, alt. } 30 \mathrm{~m}\end{array}$ & 12 & 18 \\
\hline \multirow[t]{6}{*}{ M. scabra } & 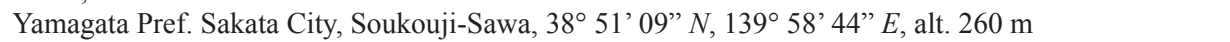 & 6 & 18 \\
\hline & Yamagata Pref., Higashine City, Izumigo, $38^{\circ} 27^{\prime} 33^{\prime \prime} N, 140^{\circ} 29^{\prime} 75^{\prime \prime} E$, alt. $470 \mathrm{~m}$ & 2 & 18 \\
\hline & Tokyo Metro., Machida City, Higashi-Tamagawagakuen, $35^{\circ} 33^{\prime} 12^{\prime \prime} N, 139^{\circ} 28^{\prime} 38^{\prime \prime} \mathrm{E}$, alt. $460 \mathrm{~m}$ & 2 & 18 \\
\hline & Fukui Pref., Ono City, Shimo-Hanbara & 4 & 18 \\
\hline & Fukui Pref., Obama City, Oya, $35^{\circ} 35^{\prime} 65^{\prime \prime} N, 136^{\circ} 07^{\prime} 57^{\prime \prime} E$, alt. $160 \mathrm{~m}$ & 4 & 18 \\
\hline & Tokushima Pref., Miyoshi City, Ikeda-cho, Mt. Wakasamine, alt. $770 \mathrm{~m}$ & 3 & 18 \\
\hline \multirow[t]{2}{*}{ M. dianthera } & 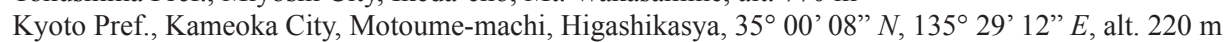 & 3 & 18 \\
\hline & Tokushima Pref., Miyoshi City, Ikeda-cho, Mt. Wakasamine, alt. 770 m & 8 & 18 \\
\hline \multirow{4}{*}{$\begin{array}{l}\text { M. dianthera } \\
\text { var. nana }\end{array}$} & Okayama Pref., katsuta-Gun, Shohoku-cho, Oiwa, $35^{\circ} 08^{\prime} 65^{\prime \prime} N, 134^{\circ} 07^{\prime} 47^{\prime \prime} E$, alt. $510 \mathrm{~m}$ & 4 & 18 \\
\hline & Okayama Pref., Tomata-Gun, Kagamino-cho, Yamashiro, $35^{\circ} 06^{\prime} 34^{\prime \prime} N, 133^{\circ} 53^{\prime} 46^{\prime \prime} E$, alt. $180 \mathrm{~m}$ & 3 & 18 \\
\hline & Okayama Pref., Maniwa City, Yonoshita, Akameiwa-rindo, $35^{\circ} 06^{\prime} 04^{\prime \prime} N, 133^{\circ} 48^{\prime} 85^{\prime \prime} E$, alt. $230 \mathrm{~m}$ & 5 & 18 \\
\hline & Okayama Pref., Kume-Gun, Misaki-cho, Utanokita, $34^{\circ} 59^{\prime} 25^{\prime \prime} N, 133^{\circ} 55^{\prime} 23^{\prime \prime} E$, alt. $290 \mathrm{~m}$ & 1 & 18 \\
\hline
\end{tabular}

*Collection site by Mr. Hiroshi Koyano (Head Curator; now Emeritus Curator)) in Sept. 1985, and cultivated in Shigei Medicinal Garden, Kurashiki, Okayama Pref.

similar karyotypes to each other except for chromosome numbers and chromosome complement with respect to centromeric positions.

Mosla japonica (Benth ex Oliv.) Maxim. is distributed in Japan and South Korea. This species is found in Hokkaido, Honshu, Shikoku and Kyushu in Japan, and grows in sunny meadows on hills or mountains; lowlands to 1,000 m (Murata and Yamazaki 1993). Six plants of this species were collected in two localities in sunny place on the rock and a forestry road-sides in Japan (Fig. 1; Table 1). They had common chromosome numbers of $2 n=36$ in all plants studied (Fig. 2B and C). This chromosome numbers verified with the previous report (Suzuka 1953). This species could be tetraploid if the basic chromosome number $\mathrm{x}=9$ was accepted. The chromosome sizes ranged from 2.1 to $1.1 \mu \mathrm{m}$ long, total chromosome length of 55.2 $\mu \mathrm{m}$ and average chromosome length of $1.54 \mu \mathrm{m}$. The chromosome complement in centromeric positions consisted median- and submedian-centromeric chromosomes. The first to fourth chromosomes were median-centromeric chromosomes (Table 2; Fig. 3A). Small dot like satellites were rarely observed on short arms in medium sized chromosomes.

Mosla chinensis Maxim. is distributed in Japan, South Korea, Taiwan and Central to South China. This species is found in West Honshu (Okayama, Hiroshima (?) and 


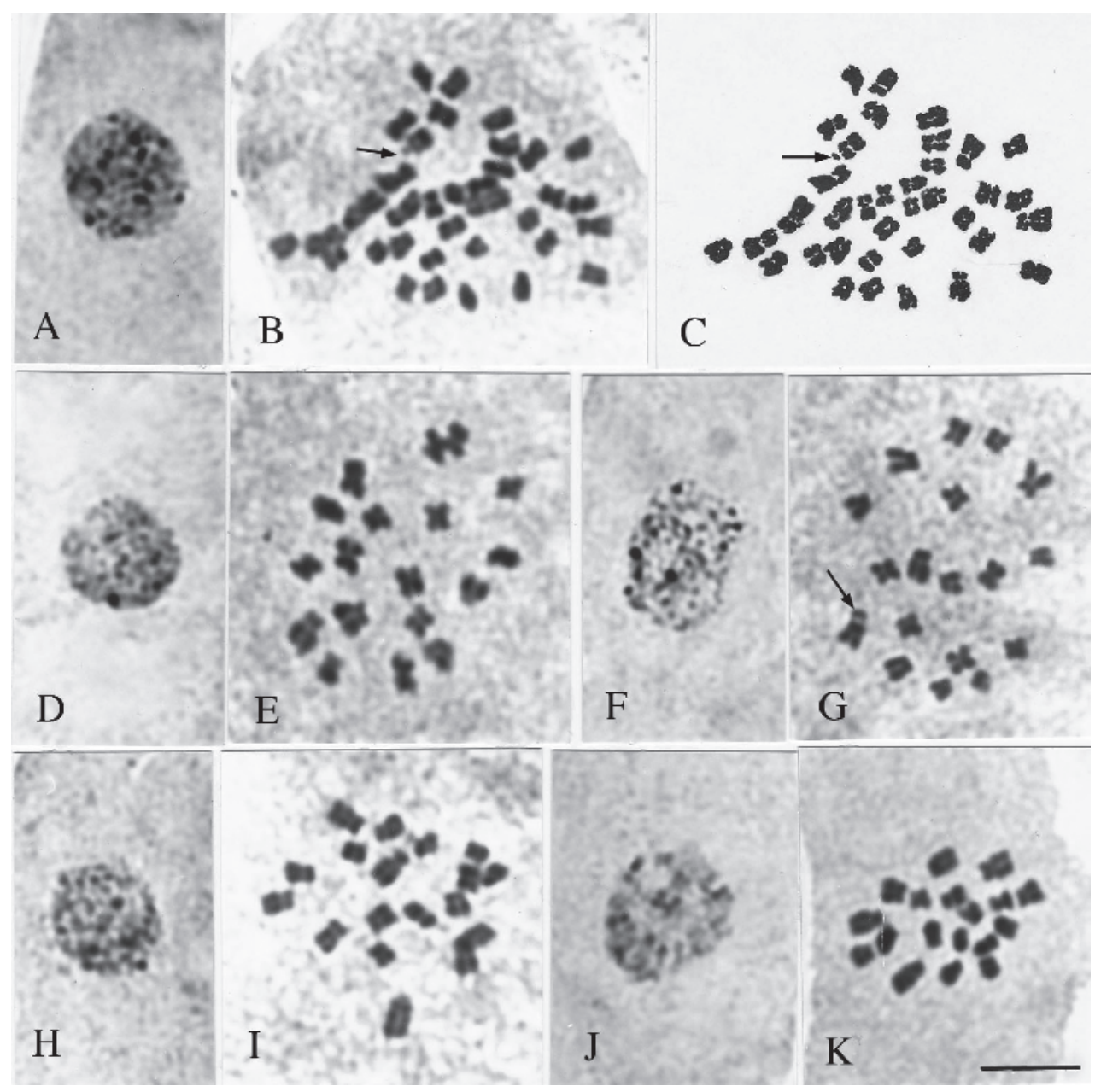

Fig. 2. Karyomorphological comparisons of resting nuclei and mitotic metaphase chromosomes in five taxa of Mosla. A, D, F, H and J: The resting nucleus; B, C, E, G, I and K: The mitotic metaphase chromosomes. A-C: $M$. japonica $(2 \mathrm{n}=36)$; D and E; $M$. chinensis $(2 \mathrm{n}=18) ; \mathrm{F}$ and G: M. scabra $(2 \mathrm{n}=18) ; \mathrm{H}$ and I: M. dianthera $(2 \mathrm{n}=18) ; \mathrm{J}$ and $\mathrm{K}$ : M. dianthera var. nana $(2 \mathrm{n}=18)$. $\mathrm{C}$ is drawing of photograph for B. Arrows indicate satellites. Scale bar $=5 \mu \mathrm{m}$.

Yamaguchi Pref.) and Kyushu (Nagasaki Pref.) in Japan, and rise in sunny, more or less dry places on hills in Japan (Murata and Yamazaki 1993). Eighteen samples of this species were collected in two localities in sunny, more or less dry places in Japan (Fig. 1; Table 1). They had the common chromosome numbers of $2 n=18$ (Fig. 2E). This chromosome numbers verified with the previous report (Zhang and Xu 1988). This species could be diploid if the basic chromosome number $\mathrm{x}=9$ was accepted. The chromosome sizes ranged from 2.1 to $1.3 \mu \mathrm{m}$ long, total chromosome length of $29.2 \mu \mathrm{m}$ and average chromosome length of $1.62 \mu \mathrm{m}$. The chromosome complement in centromeric positions was consisted of median- and submedian-centromeric chromosomes. The first and second chromosomes were submedian-centromeric (Table 2; Fig. 3B). Any satellited chromosome has never been observed.

Mosla scabra (Thunb.) C. Y. Wu et H. W. Li [=M. punctulata (J. F. Gmel.) Nakai] is distributed in Japan, South Korea, Taiwan, Central and South China and Vietnam. This species is found in Hokkaido, Honshu, Shikoku, Kyushu and Ryukyu in Japan and rise in sunny meadows; lowlands to $1,000 \mathrm{~m}$ (Murata and Yamazaki 1993). Twenty-one samples of this species were collected in six localities in sunny meadows in Japan (Fig. 1; Table 1). They had common chromosome numbers of $2 \mathrm{n}=18$ in the individual plants studied (Fig. 2G). This chromosome number verified with the previous reports (Sugiura 1931, 1936; Zhang and Xu 1988; Hsieh and Huang 1999). This species could be diploid if the basic chromosome number $\mathrm{x}=9$ was accepted. The chromosome sizes ranged from 2.0 to $1.1 \mu \mathrm{m}$ long, total chromosome length of $27.5 \mu \mathrm{m}$ and average chromosome length of $1.53 \mu \mathrm{m}$. The chromosome complement consisted of median- and submediancentromeric chromosomes. The first to fourth chromosomes were submedian-centromeric chromosomes (Table 2; Fig. 3C). A little large dot like satellites were rarely observed on short arms in medium sized chromosomes.

Mosla dianthera (Buch.-Ham. ex Roxb.) Maxim. (=M. ocimoides Bunch. -Ham. ex Benth.) is distributed in Japan, Korea, China, Far East in Russia, Southeast Asia and North India. This species is found from Hokkaido to 
Table 2. Karyotype comparisons in five taxa of Mosla observed here

\begin{tabular}{|c|c|c|c|c|c|c|}
\hline \multirow[b]{2}{*}{ Species } & \multirow[b]{2}{*}{$\begin{array}{l}\text { Chromosome } \\
\text { number }(2 n)\end{array}$} & \multicolumn{4}{|c|}{ Chromosome length $(\mu \mathrm{m})$} & \multirow[b]{2}{*}{ Form } \\
\hline & & $\begin{array}{c}\text { Longest } \pm \text { SD } \\
\text { (Range) }\end{array}$ & $\begin{array}{l}\text { Shortest } \pm \text { SD } \\
\text { (Range) }\end{array}$ & $\begin{array}{c}\text { Total } \pm \text { SD } \\
\text { (Range) }\end{array}$ & $\begin{array}{c}\text { Average } \pm \text { SD } \\
\text { (Range) }\end{array}$ & \\
\hline M. japonica & 36 & $\begin{array}{c}2.1 \pm 0.23 \\
(2.0-2.4)\end{array}$ & $\begin{array}{l}1.1 \pm-.06 \\
(1.1-1.2)\end{array}$ & $\begin{array}{l}55.2 \pm 2.65 \\
(52.5-57.8)\end{array}$ & $\begin{array}{l}1.54 \pm 0.08 \\
(1.46-1.61)\end{array}$ & $\mathrm{m}+\mathrm{sm}$ \\
\hline M. chinensis & 18 & $\begin{array}{c}2.1 \pm 0.35 \\
(1.7-2.6)\end{array}$ & $\begin{array}{c}1.3 \pm 0.23 \\
(1.0-1.7)\end{array}$ & $\begin{array}{l}29.2 \pm 4.35 \\
(23.9-36.8)\end{array}$ & $\begin{array}{l}1.62 \pm 0.23 \\
(1.33-2.0)\end{array}$ & $\mathrm{m}+\mathrm{sm}$ \\
\hline M. scabra & 18 & $\begin{array}{c}2.0 \pm 0.29 \\
(1.6-2.4)\end{array}$ & $\begin{array}{c}1.1 \pm 0.15 \\
(1.0-1.4)\end{array}$ & $\begin{array}{l}27.5 \pm 3.38 \\
(24.3-33.2)\end{array}$ & $\begin{array}{l}1.53 \pm 0.19 \\
(1.35-1.84)\end{array}$ & $\mathrm{m}+\mathrm{sm}$ \\
\hline M. dianthera & 18 & $\begin{array}{c}2.2 \pm 0.18 \\
(1.9-2.4)\end{array}$ & $\begin{array}{c}1.2 \pm 0.11 \\
(1.0-1.3)\end{array}$ & $\begin{array}{l}27.8 \pm 2.24 \\
(24.8-30.4)\end{array}$ & $\begin{array}{l}1.55 \pm 0.12 \\
(1.38-1.69)\end{array}$ & $\mathrm{m}+\mathrm{sm}$ \\
\hline $\begin{array}{l}\text { M. dianthera } \\
\text { var. nana }\end{array}$ & 18 & $\begin{array}{c}2.0 \pm 0.25 \\
(1.7-2.3)\end{array}$ & $\begin{array}{c}1.1 \pm 0.14 \\
(0.9-1.2)\end{array}$ & $\begin{array}{l}26.8 \pm 2.75 \\
(23.6-30.3)\end{array}$ & $\begin{array}{l}1.49 \pm 0.15 \\
(1.31-1.68)\end{array}$ & $\mathrm{m}+\mathrm{sm}$ \\
\hline
\end{tabular}

SD: standard deviation; m: median-centromeric chromosome; sm: submedian-centromeric chromosome

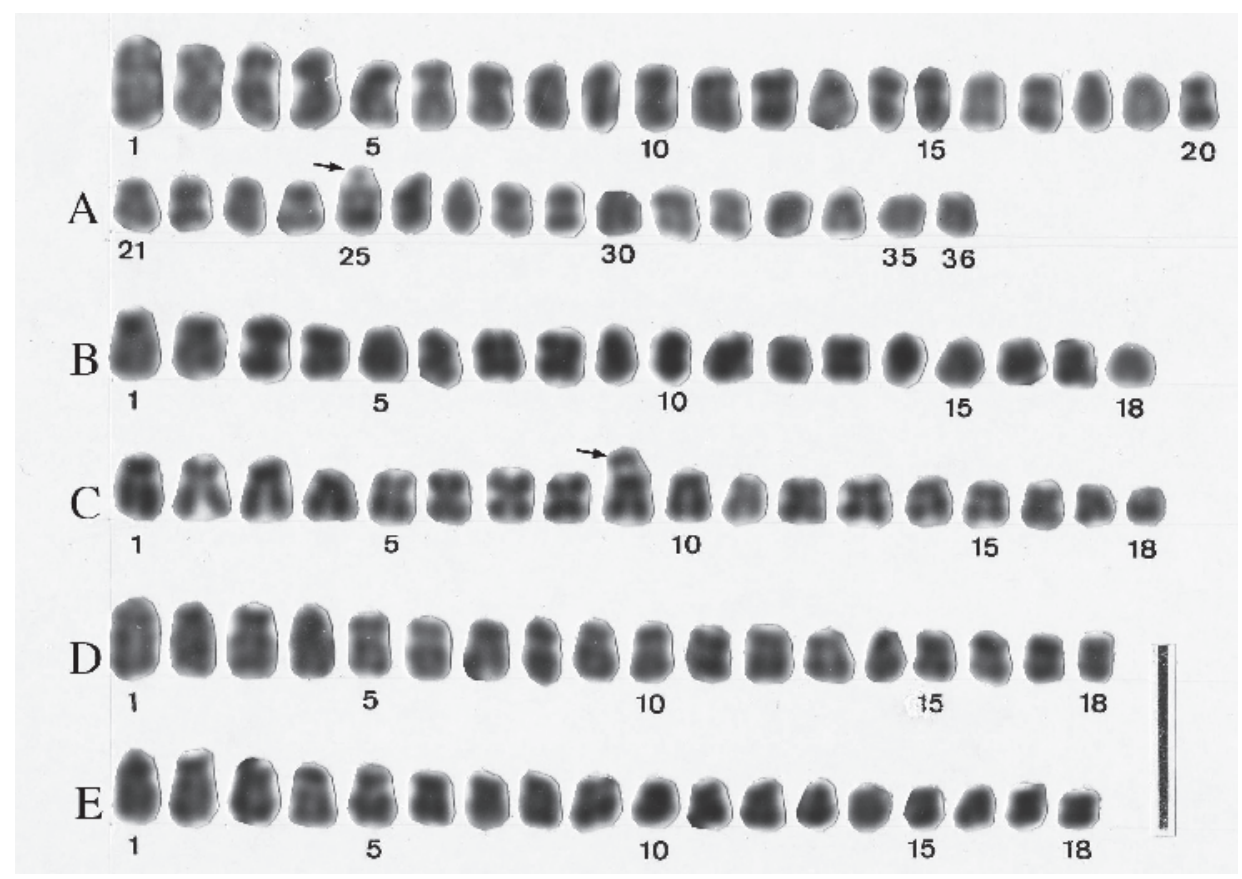

Fig. 3. Karyotype comparisons in five taxa of Mosla. A: M. japonica; B: M. chinensis; C: $M$. scabra; D: M. dianthera; E: $M$. dianthera var. nana. Arrows indicate satellites. Scale bar $=5 \mu \mathrm{m}$.

Ryukyu in Japan and rise in sunny meadows; lowlands to about $700 \mathrm{~m}$ (Murata and Yamazaki 1993). Eleven samples of the species were collected in two localities in sunny meadows in Japan (Fig. 1; Table 1). They had common chromosome numbers of $2 \mathrm{n}=18$ in all plants (Fig. 2I). This chromosome numbers verified with the previous reports (e.g. Provatova and Sokolovskaya 1986; Sokolovskaya et al. 1986; Zhang and Xu 1988; Hsieh and Huang 1999). This species could be diploid if the basic chromosome number of $\mathrm{x}=9$ was accepted. The chromosome sizes ranged from 2.2 to $1.2 \mu \mathrm{m}$ long, total chromosome length of $27.8 \mu \mathrm{m}$ and average chromosome length of $1.55 \mu \mathrm{m}$. The chromosome complement in centromeric positions consisted median- and submediancentromeric chromosomes. The first to sixth chromosomes were submedian-centromeric (Table 2; Fig. 3D). A little large dot like satellites were rarely observed on the short arms of the medium-sized chromosomes.

Mosla dianthera (Buch.-Ham. ex Roxb.) Maxim. var. nana (Hara) Ohwi (= M. hirta Hara) is distributed in Japan, South Korea and Taiwan. This species is found in Honshu, Shikoku and Kyushu in Japan and rise in edge of forests in mountains (Murata and Yamazaki 1993). Thirteen samples of this species were collected in four localities in edge of forests in mountains in Japan (Fig. 1; Table 1). They had common chromosome numbers of $2 \mathrm{n}=18$ in all plants (Fig. $2 \mathrm{~K}$ ). The chromosome numbers of this species was reported here for the first time. This species could be diploid if the basic chromosome number $\mathrm{x}=9$ was accepted. The chromosome sizes ranged from 2.0 to $1.1 \mu \mathrm{m}$ long, total chromosome length of $26.8 \mu \mathrm{m}$ and average chromosome length of $1.49 \mu \mathrm{m}$. The chromosome complement in centromeric positions consisted of either 
median- and submedian-centromeric chromosomes. The first to sixth chromosomes were submedian-centromeric chromosomes (Table 2; Fig. 3E). A little large dot like satellites were rarely observed on the short arms in the medium sized chromosomes.

Mosla is placed in subtribe Perillineae, tribe Saturejeae, subfam. Lamioideae taxonomically (Wu and Li 1977a) and divided in sect. Orthodon and sect. Mosla (Wu et al. 1965; Wu and Li 1977b). Japanese Mosla, section Orthodon included M. japonica and M. chinensis, while sect. Mosla included M. scabra, M. dianthera and M. dianthera var. nana (Murata and Yamazaki 1993). Thus, five taxa for Japanese Mosla had the same complex chromocenter type of the resting nuclei, and had the stable basic number of $\mathrm{x}=9$ except for chromosome numbers, detailed forms for centromeric positions of large sized chromosomes and sizes of satellites between inter- or intra-sections as described above. Chromosome studies of many more species are necessary to clarify and justify cytotaxonomical relationships for Mosla.

ACKNOWLEDGMENTS. We thank Prof. Dr. Katsuhiko Kondo, Tokyo University of Agriculture, for valuable advice and critical reading manuscript, and also thank to members of the Yamaguchi Prefecture Yagai-shokubutsu Kenkyu-Iinkai and to Mr. Hiroyuki Kataoka, Head Curator of Shigei Medicinal Garden to locate Mosla chinensis in Yamaguchi and Okayama Prefectures.

\section{Literature Cited}

Funamoto, T. 2007. Comparative chromosomal characters of three Japanese species in Chelonopsis, Lamiaceae. Chrom. Bot. 2: 63-66.

Funamoto, T., Kondo, K., Smirnov, S. V., Tatarenko, I. V., Motohashi, T. and Damdinsuren, O. 2008. A comparison of chromosome characters in three species of Thymus (Lamiaceae) collected in Russia and Mongolian Altai. Chrom. Bot. 3: 1-6.

Funamoto, T., Kondo, K. and Motohashi, T. 2009. Comparison of karyomorphological characters in four Japanese species of Lycopus and Russian L. europaeus, Lamiaceae. Chrom. Bot. 4: 71-77.

Funamoto, T. and Smirnov, S. V. 2011. Comparative karyomorphological studies in three species of Dracocepharum L. (Lamiaceae) in Altai Mountains, Russia and Mongolia. Chrom. Bot. 6: 107-110.

Funamoto, T., Xhang, C. 1., Ogawa, M. and Peng, H. 2012. A comparative study of chromosome characters in four species of Elsholtzia Will. (Lamiaceae) in Japan and China. Chrom. Bot. 7: 119-123.

Gill, L. S. 1971. Cytology of west-Himalayan Labiatae: tribe
Satureineae. Caryologia 24: 203-207.

Gill, L. S. 1984. The incidence of polyploidy in the WestHimalayan Labiatae. Rev. Cytol. Biol. Vég. Bot. 7: 5-16.

Hsieh, T. H. and Huang, T. C. 1999. Revision of Mosla (Lamiaceae) in Taiwan. Taiwania 44: 72-81.

Levan, A., Fredga, K. and Sandberg, A. A. 1964. Nomenclature for centromeric position on chromosomes. Hereditas 52: 201-220.

Li, H. W. and Hedge, I. C. 1994. Mosla (Benth.) Buch.-Ham. ex Maxim., In Flora of China Vol. 17 Verbenaceae through Solanaceae, pp. 242-245, Wu, Z. Y. and Raven, P. H. (eds.), Science Press (Beijing) and Missouri Botanical Garden (St. Louis).

Mehra, P. N. and Gill, L. S. 1968. In IOPB chromosome number reports XVIII. Taxon 17: 419-422.

Murata, G. and Yamazaki, T. 1993. Mosla Buch.-Ham. ex Maxim., pp. 287-288. In Flora of Japan IIIa, Iwatsuki, K., Yamazaki, T., Boufford, D. E. and Ohba, H. (eds.), Kodansha, Japan.

Probatova, N. S. and Sokolovskaya, A. P. 1986. Chromosome numbers of the vascular plants from the far east of the USSR. Bot. Zhurn. 71: 1572-1575 (in Russian).

Sokolovskaya, A. P. , Probatova, N. S. and Rudyka, E. G. 1986. A contribution to the study of chromosome numbers and geographical distribution of some species of the family Lamiaceae in the Soviet far east. Bot. Zhurn. 71: 195-200 (in Russian).

Sugiura, T. 1931. Alist of chromosome numbers in angeospermous plants. Bot. Mag. Tokyo 45: 353-355.

Sugiura, T. 1936. Studies on the chromosome numbers in higher plants, with special reference to cytokinesis I. Cytologia 7: 544-595.

Tanaka, R. 1971. Types of resting nuclei in Orchidaceae. Bot. Mag. Tokyo 84: 118-122.

Tanaka, R. 1977. Recent karyotype studies, In Plant Cytology, Ogawa, K., Kurozumi, K., Koike, S. and Sato, S. (eds.). pp. 293-326, Asakura Book, Tokyo, Japan (in Japanese).

Suzuka, O. 1953. Chromosome numbers in pharmaceutical plants II. Seiken Zihô 6: 79.

Wu, C. Y., Li, H. W., Hsuan, S. J. and Huang Y. C. 1965. Materiae ad Floram Labiatarum Sinensium (2). Acta Phytotax. Sin. 10: 215-242 (in Latin).

Wu, C. Y. and Li, H. W. 1977a. Labiatae, In Flora Reipublicae Popularis Sinicae Tomus 65 (2), Angeospermae Dicotyledonae Labiatae (1), Wu, C. Y. and Li, H. W. (eds.), pp. 1-18, Institutum Botanicum Provinciae Yunnanicae nd Institutum Botanicum Pekinense Academiae Sinica, P. R. of China (in Chinese).

Wu, C. Y. and Li, H. W. 1977b. Mosla Buch.-Ham. ex Maxim., In Flora Reipublicae Popularis Sinicae Tomus 66, Angeospermae Dicotyledonae Labiatae (2), Wu, C. Y. and Li, H. W. (eds.), pp. 287-300, Institutum Botanicum Provinciae Yunnanicae collegium Pharmaceuticum Nankingense, P. R. of China (in Chinese).

Zhang, S. Y. and Xu, B. S. 1988. A study on the variation patterns of Mosla in the Yangtye Delta at population level. Acta Bot. Yunnan. 10: 409-412 (in Chinese with English abstract). 
